\title{
INTEGRATION OF VALUE ADDING SERVICES RELATED TO FINANCING AND OWNERSHIP: A BUSINESS MODEL PERSPECTIVE
}

\author{
Tauqeer, Muhammad; Bang, Knut Erik \\ University of Stavanger
}

\begin{abstract}
It is an agreed fact among scholars that services are more sustainable compared to the products. By offering services, traditional companies can lock their customers into a long-term and sustainable revenue generation settlement. Available academic literature is abundant with methodologies related to service development. However, this study investigates various value adding service options related to financing and ownership of a product that can be offered on top of the existing products. It is important to understand these options from the consumer as well as supplier perspective. The most well established options available for financing/ownership are compiled, and sorted with respect to intangibility, ownership, financing and value addition scale. The study argues that the identified options incrementally add value to the existing offering by increasing the purchasing power and reducing the ownership obstacles for the customers. However, for the supplier, the decision depends on the trade-off between value addition for the customers and the business model changes required.
\end{abstract}

Keywords: Service design, Product-Service Systems (PSS), Business models and considerations

\section{Contact:}

Tauqeer, Muhammad

University of Stavanger

IMBM

Norway

muhammad.a.tauqeer@uis.no

Cite this article: Tauqeer, M., Bang, K.E. (2019) 'Integration of Value Adding Services Related to Financing and Ownership: A Business Model Perspective', in Proceedings of the 22nd International Conference on Engineering Design (ICED19), Delft, The Netherlands, 5-8 August 2019. DOI:10.1017/dsi.2019.234 


\section{INTRODUCTION}

According to Vargo and Lusch (2008), a paradigm evolution has taken place concerning businesses that they are shifting from selling products to offering services. Globally, services are not only larger than any other segment but also more sustainable (Chesbrough, 2011). This dominance is due to the fact that customers, in general, are not interested in the products but in the utility that the product provides to them, (Druker, 1975) which is called as a service (Tauqeer and Bang, 2018). The product life cycle has also significantly reduced in the present era and companies are increasingly competing against each other to launch new products. It is difficult for many companies to participate in this race and therefore, a tentative solution is needed. One of the solutions to this dilemma is to shift the business model from selling products only to offering services together with the products (Chesbrough, 2011). According to Olivia and Kallenberg (2003), service integration does not primarily involve any technological changes but includes modifying the business model. This implies that it is not mandatory to have technological advances in order to integrate new services.

Existing literature on service development includes service development process cycles with idea generation, design, development, testing, and launch stages (e.g. Johnson et al., 2000; Aurich et al., 2006). Similarly, studies by Olivia and Kallenberg (2003); Gebauer and Fleisch (2007); and Kowalkowski et al. (2015) have mentioned levels of services that are product-related (i.e., first level), installed base (i.e., second level) and integrated solutions (i.e., third level). Several studies have applied the product-service system models in industrial applications, e.g., by Van Halen et al. (2005); Sakao and Shimomura (2007); Vasantha et al. (2012); Pigosso and McAloone (2016); and Fargnoli et al. (2018) to develop new service concepts. According to Sun et al. (2009), the product needs to be designed in a way that additional services can be added. Scholars have also emphasised the relationship between services and business model (Chesbrough, 2011; Eggert et al., 2011; Visinjic et al., 2014).

Companies around the world are increasingly looking for service opportunities that can increase their revenue from their current product ranges. Not much research has been done on this topic and available literature provides marginal assistance in this regard. This study looks into the financing/ownership service options from the consumer and supplier's perspective. In addition, changes in the business model that the business owners need to make while perusing any of these options are investigated. In principle, services can be offered in various ways for instance, as technological services, value-adding services, after sales services, product-service system etc. However, due to the limited scope of this study, only value-adding services related to financing and ownership of the product are discussed.

From the literature review, the research question identified is:

What changes financing/ownership options bring to the business model of the company while transforming the product into service?

The remaining paper is organised as: First, the financing/ownership value adding service options collected through literature review are presented proceeded by, studying the impact of these options on the business model of a company.

\section{SERVICE INTEGRATION OPTIONS}

The service options related to financing/ownership that can be selected by a company are collected through rigorously reviewing the literature and are shown in Figure 1. They are sorted with respect to intangibility, ownership, financing, and value addition. In the present context, intangibility is the measure of ownership of the product therefore; intangibility, value addition, financing and ownership are coupled parameters. The higher the intangibility, less the ownership of the product, which eases financing of the product for the customer and results in value addition for the customer. Correlation of these parameters is shown in Figure 1.

Financing reflects the channels that the customer can pay through in order to purchase an offering. Whereas, ownership implies various challenges that the customer faces after purchasing an offering such as operational cost, depreciation cost, annual premiums/tax, liabilities, and product storage. From the service perspective, financing and ownership are primarily analogous to each other, as the type of financing scheme directly affects the ownership of the product. 


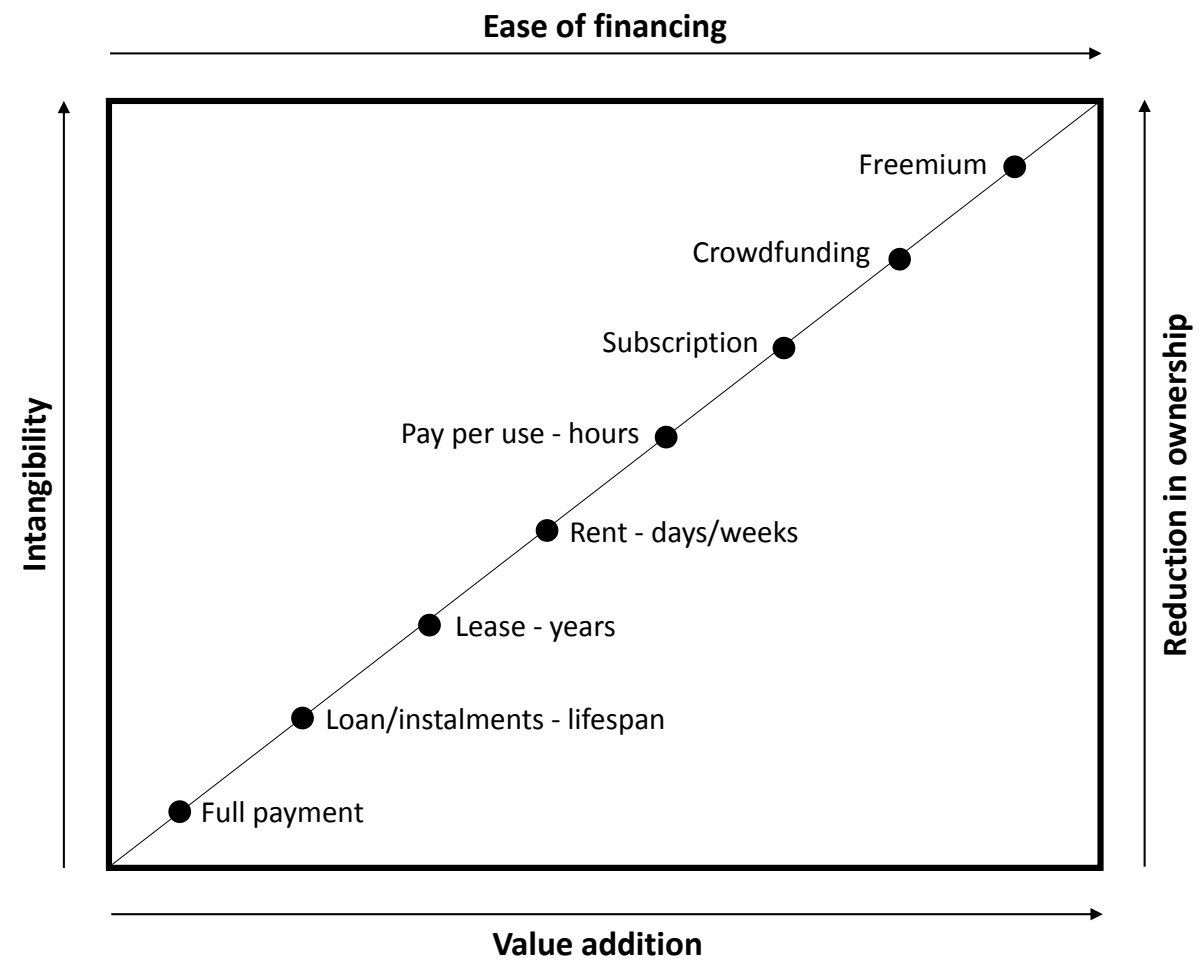

Figure 1. Financing/ownership options sorted with respect to intangibility, ownership, financing, and value addition capability for the customers

A company can increase the value of its existing product by gradually offering the options on top of the product (Figure 1). These options are sorted in accordance to their potential to servitize an offering. The options higher up on the scale eliminates more ownership traits from the offering compared to the rest. Options up on the scale may not be applicable to all products, however, those low on the scale can generally be applied to all products. Hence, options need to be gradually checked from the bottom of the scale to the top. Figure 2 shows the effects of integrating the financing/ownership service options listed in Figure 1, on the product. At each step on the scale shown in Figure 1, company adds value to the customers, resulting in increased company's sales. This will also give a competitive advantage and raise the general standing of the company and by that the prospects.

Although adding to the offering may add value to the customer and increase the competitive strength of the company in the market, this might not directly lead to added revenue. Added customer value might lead to more sales, but the basis to generate revenue may change. By offering financing of the product, revenue basis is expanded to include interest on loans or from leasing. However, by not setting up financing options as the new business processes but instead co-operating with other companies in order to provide the expanded services, the company may not fully capitalise in the revenues resulting from these options. However, cooperation can lead to higher sales and the company will then neither be exposed to the risks associated with these added services. This is one of the major trade-offs that has to be done. Adding to the offerings by adding new processes will also add to the competence and capital requirements.

Figure 1 shows us two important points. First, there are options available for further servitization of the product by offering value adding services. Second, there might be several major consequences to the business model of the company by pursuing those options. What we see from Figure 2 is that when a company adds a service to an offering, it adds value to both customers and the company. The consequence is that as a company it may not have a choice. If the competitors are increasing attractivity of their products by adding these services, a company that is not doing it will fall behind in the competition, hence cannot afford that to happen. This can mean that if there are opportunities for further servitization of the products, they must be pursued to stay ahead in the competition. There is really no choice, and it may be one of the contributing factors in driving the increase in services. The choice is more on whether the new offerings should be provided through new processes internally or set up through co-operation with other companies. This consideration depends on the increased 
revenue versus the increased risks, and the availability of resources and financing for building the processes.

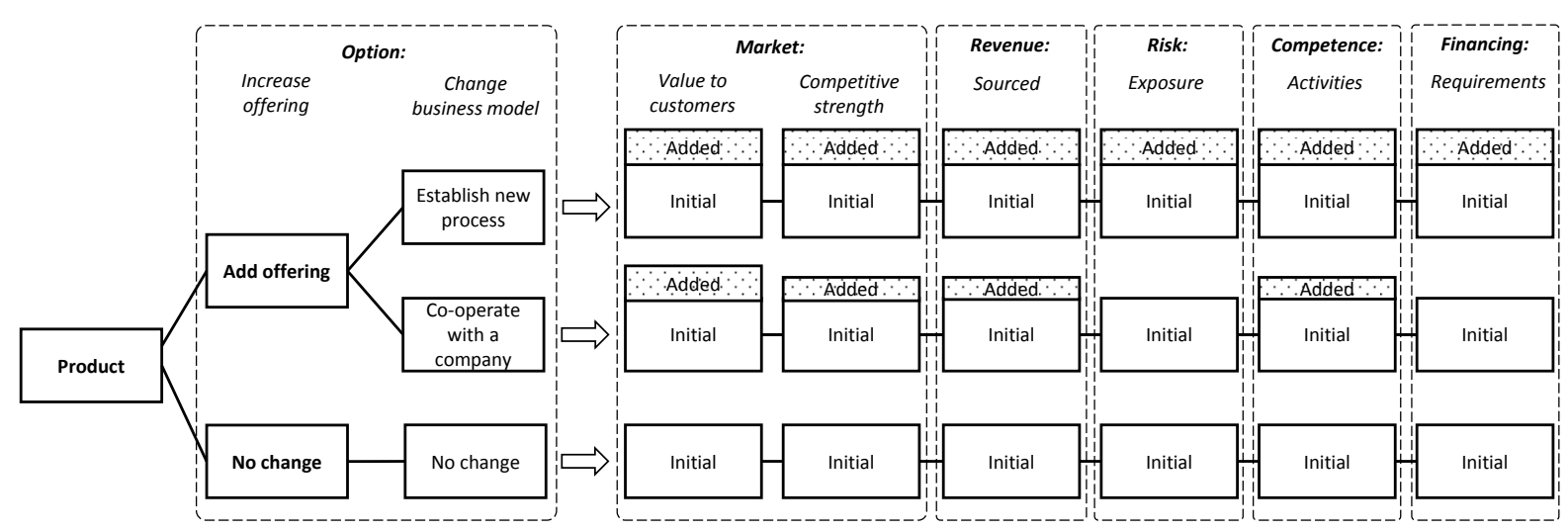

Figure 2. Decision tree for the implementation of the financing/ownership options in the business model

\section{EFFECT OF THE SERVICE OPTIONS ON THE BUSINESS MODEL}

In their study, Olivia and Kallenberg (2003) analysed different companies, which were shifting from products to services, and discovered that the transition primarily involved a change in business models. In the present study, financing/ownership options are inferred to be the major difference in the business model of the companies shifting from products to services. For example, a car is a product if owned by a user but becomes a service if rented. This involves only the difference in ownership and financing of the car. In the previous section, the effect of the options listed in Figure 1 is observed from the consumers' perspective and it appears that the offering becomes more likely to be purchased if it is offered through the options up on the scale. Therefore, in order to grow customer base, companies need to transform their business models so that they offer rent, lease or subscription services on top of their products. However, it is important to investigate what changes are required in the business model, revenue model, financial requirements, competence requirements, regulatory requirements, and risks in order to offer these services. These changes are summarised in Figure 3.

\subsection{Sales}

A Sale is selling of products to the customers at the agreed price. The customer pays in full for the product and fully owns that product. Sales are the most common mode of revenue generation for the sellers. However, as discussed earlier, sales of the products are not sustainable in the present rapidly evolving market. Therefore, alternative methods need to be studied so that the product offering is transformed towards service side for a sustainable revenue stream. Nokia was the world leader in cell phone business (Surowiecki, 2013) but it was unable to compete against the rapidly evolving product businesses. Contrarily, Google offers most of its products as freemium, which are resulting in longterm sustainable revenue stream.

The remaining options shown in Figure 3 are studied in comparison to sales so that the relative difference can be understood.

\subsection{Loan}

The largest barrier for many customers is the cost of the product. Many companies (like GM and GM money bank) have moved from not only providing products but also enabling customers to buy the products. Such a strategy definitely effects the company's business and revenue model, yet, it offers a competitive advantage in its primary market of selling the products in comparison to companies that do not provide these extra-integrated services. Providing loan along with the product is one of the option to reduce purchasing barrier for the customer and it is a well-known approach. However, we see fewer examples of companies that consider providing loan as an alternate option to the consumers.

For most consumers buying expensive products with full payment is a challenge. To tackle this issue, business owners have two possibilities to offer loans in parallel to their product sales. Either they can cooperate with a bank or they can change their business model from production only to production plus 
banking. This will change their revenue model from sales only to sales plus interest earnings. It is interesting to investigate what new resources the company would require when its business model is changed from production only to production plus banking. Theoretically speaking, the financial requirements to provide loans is the same as production with an estimated ten percent of the sales value. This implies that the company need not to establish a large bank with significant customer deposits. Ten percent of the sales is manageable by most of the companies. However, new banking competence would be required to setup customer contracts managing the loan collection system. Similarly, the company will require banking licenses. This option has debt recovery risks associated with it but the risk is low considering the recovery rates of banks in the present time. Considering these requirements, it should be possible for small business owners such as grocery stores and hardware stores to provide loans. IKEA a furniture seller also offer loans to the customers (IKEA, 2019).

\subsection{Lease}

The lease option is identical to loan option in many aspects, however, differs in terms of ownership. The leased product has distributed ownership between customer and supplier contrary to a loan where the product is fully owned by the consumer. The lease is time-bound where the consumer partially owns the product during the lease period.

In order to provide leasing service, companies can either establish a co-operation with existing leasing company or establish a leasing company. The business model will transform into production plus leasing and generate revenue through sales as well as leasing. Leasing requires increased capital requirement than rental since the consumer pays only during the lease period. Higher competence is required to capitalise the products received at the end of the lease agreement. In addition to rental risks, it also includes uncertainty risk of the remaining life of the product. For example, the value of smartphones exponentially decreases over time and therefore, it is difficult to estimate the rest value after the maturity of the lease agreement. Traditionally, houses and cars were leased. Nowadays smartphone and computer lease options are also available in the market. However, considering the increased customer requirements, it should be possible to lease lawn movers, household equipment and simple items like kitchen electronics.

\subsection{Rent}

Next on the scale is renting option. It shares many similarities with the lease option but differs based on duration. This option is typically availed by the users for relatively shorter durations. The business and revenue models require renting competence in addition to the existing competence. The financial requirements are higher in order to meet the operational expenses. Generally, it is possible to maintain the renting business with additional working capital of roughly $20 \%$. The regulatory requirements essentially remains same however, there is significant change in the risk level. The service provider needs to incorporate maintenance and depreciation risks in the business model.

\subsection{Pay-per-use}

In pay-per-use, the consumer is charged for a short period only when the service is availed. For example Taxi service where the consumer only pays for the ride. Similarly, jet engine manufacturers (e.g., Rolls Royce and GE) have also started charging their customers by 'pay-by-hour' where the operations and maintenance activities are kept by the supplier and consumer is charged for the utility provided.

Pay-per-use implementation would require the addition of facilitation activities in the business model (i.e., operation, maintenance etc.). It requires higher capital to own products and operate them. Increased competence in operation and maintenance activities are essential and involves associated risks. An additional risk of demand fluctuations is also present. Pay-per-use model is useful for products that have low utilization by the consumers. For example, a welding machine. Pay-per-use is not suitable for products that have high utilization such as smartphones.

\subsection{Subscription}

Altering the business model to subscription requires subscription facilitation unit in the company, which can be either developed by the company or a co-operation can be set up within the existing company. Subscription is a source to generate a long-term revenue stream for the company. Subscription is similar to pay-per-use but the consumer is engaged into a long-term periodic revenue-providing stream. It is 
equally suitable for less tangible offerings such as digital library subscription and tangible offerings like car subscription. However, subscription option is also vulnerable to rapid demand change risk. Demand increase is manageable in the case of intangible offerings where replicability is not a problem but if the offering is disliked by the consumer, less revenue is generated compared to sales. For tangible offerings, both demand increase and decrease have consequences. Therefore, the subscription option is suitable for market verified and accepted products.

\subsection{Crowdfunding}

Crowdfunding is the practice of using crowd to finance a project. The business model for crowdfunding can be comprehensively called integrated consumer development. The unique advantage in crowdfunding is that customer feedback and sales can be made prior to the completion of the project. Therefore, it is also a tool for customer validation of the supplier's concept. The revenue model includes sales as well as upfront payments. Crowdfunding is primarily a sourcing model; therefore, the capital requirements are less than any other option due to the upfront payment by the customers. It also drastically reduces financial and market risks as the customers are paying before the production of the products. It is very suitable for untested and high-risk products and require a platform where the crowd can be gathered. Companies can use existing platforms or establish their own platforms in order to crowdfund products or projects.

\subsection{Freemium}

Freemium is a pricing approach by which an offering is provided free of charge, but capital is generated on additional benefits or through an alternate source such as an advertisement or data subletting. The business model required for freemium to work is integrated customer development through indispensable relationship. For smaller companies, it is difficult to manage indispensability with customers. However, large companies like Google have freemium as the principal revenue generation model where the end users are essentially paying nothing. Services that are free of cost and yet valuable for the customers make the indispensability possible.

Considering the sustainability of all the options compiled in Figure 1, freemium is the most sustainable ensuring long-term revenue generation financing model. However, managing indispensability with the customer is the key challenge. Currently, freemium is mostly applicable to intangible offerings. However, in the future, it would be possible to offer air rides as freemium. Through electrification and complete automation of the aviation industry, maintenance and fuel costs can be reduced close to zero thriving the possibility for aviation industry to operate on freemium model.

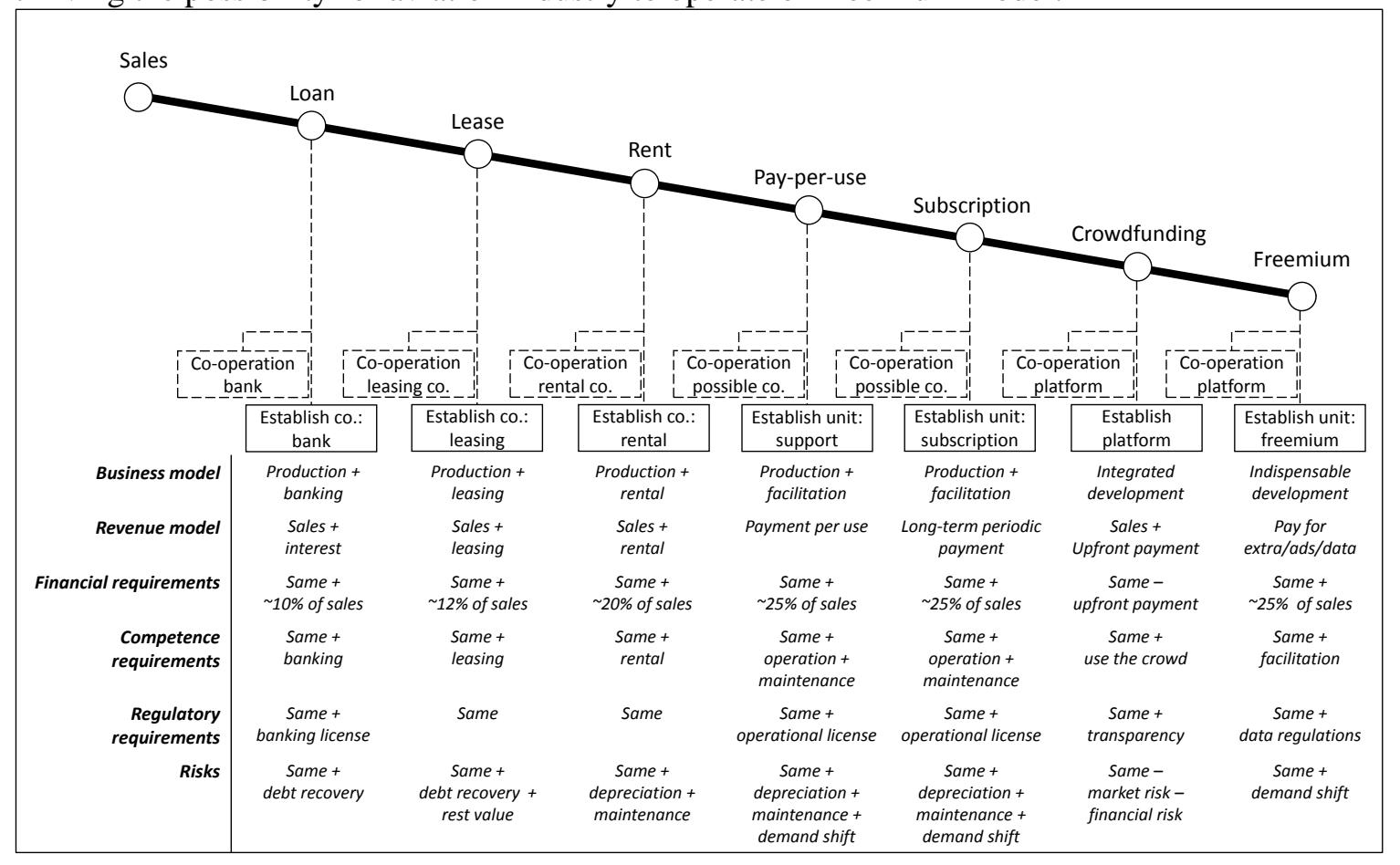

Figure 3. Summary of options for financing/ownership selection from supplier's perspective 


\section{CONCLUSIONS}

This study presents service development options related to financing and ownership, which do not require any technological development or product alteration. The options presented are well established previously but business owners do not consider all of them in a systematic way and may select a less suitable financing model for their business. Therefore, the compilation of all these options allow the user to go through them one at a time and assist them in selecting the options that can add value to their offering. Further, changes in the business model that needs to be carried out while implementing these options are also highlighted. The study shows that the options listed low on the scale appear difficult to implement but require significantly fewer resources such that they can be implemented to almost any product, e.g., it is possible to lease or rent any everyday product. Contrarily, options that are high on the scale are relatively difficult to get to work, for example, freemium option. Therefore, business owner needs to establish a trade-off between implementation complexity and the consumers' ease as the governing criteria to select the options.

\section{REFERENCES}

Aurich, J.C., Fuchs, C. and Wagenknecht, C. (2006), "Life cycle oriented design of technical Product-Service Systems", Journal of Cleaner Production, Vol. 14 No. 17, pp. 1480-1494. https://doi.org/10.1016/j.jclepro.2006.01.019

Chesbrough, H.W. (2011), "Bringing open innovation to services", MIT sloan management review, Vol. 52 No. 2, p. 85 .

Drucker, P.F. (1975), “Management: Tasks, responsibilities, practices”, truman talley Books. https://doi.org/10.2307/2230551

Eggert, A., Hogreve, J., Ulaga, W. and Muenkhoff, E. (2011), "Industrial services, product innovations, and firm profitability: A multiple-group latent growth curve analysis", Industrial Marketing Management, Vol. 40 No. 5, pp. 661-670. https://doi.org/10.1016/j.indmarman.2011.05.007

Fargnoli, M., Costantino, F., Di Gravio, G. and Tronci, M. (2018), "Product service-systems implementation: A customized framework to enhance sustainability and customer satisfaction", Journal of Cleaner Production, Vol. 188, pp. 387-401. https://doi.org/10.1016/j.jclepro.2018.03.315

Gebauer, H. and Fleisch, E. (2007), "An investigation of the relationship between behavioral processes, motivation, investments in the service business and service revenue", Industrial Marketing Management, Vol. 36 No. 3, pp. 337-348. https://doi.org/10.1016/j.indmarman.2005.09.005

IKEA (2019), Services at - Finance. Available at: (https://www.ikea.com/gb/en/customer-service/services-atikea/finance/) (25.02.2019).

Johnson, S.P., Menor, L.J., Roth, A.V. and Chase, R.B. (2000), "A critical evaluation of the new service development process", New service development: Creating memorable experiences, pp. 1-32. https://doi.org/10.4135/9781452205564.n1

Kowalkowski, C., Windahl, C., Kindström, D. and Gebauer, H. (2015), "What service transition? Rethinking established assumptions about manufacturers' service-led growth strategies", Industrial Marketing Management, Vol. 45, pp. 59-69. https://doi.org/10.1016/j.indmarman.2015.02.016

Oliva, R. and Kallenberg, R. (2003), "Managing the transition from products to services", International journal of service industry management, Vol. 14 No. 2, pp. 160-172. https://doi.org/10.1108/09564230310474138

Pigosso, D.C. and McAloone, T.C. (2016), "Maturity-based approach for the development of environmentally sustainable product/service-systems",CIRP Journal of Manufacturing Science and Technology, Vol. 15, pp. 33-41. https://doi.org/10.1016/j.cirpj.2016.04.003

Sakao, T. and Shimomura, Y. (2007), "Service Engineering: a novel engineering discipline for producers to increase value combining service and product", Journal of Cleaner Production, Vol. 15 No. 6, pp. 590 604. https://doi.org/10.1016/j.jclepro.2006.05.015

Sun, H.B., Mo, R. and Chang, Z.Y. (2009), "Study on product service oriented enterprise servitization methods", In Materials Science Forum (Vol. 626, pp. 747-752), Trans Tech Publications. https://doi.org/10.4028/www.scientific.net/msf.626-627.747

Surowiecki, J. (2013), Where Nokia went wrong. The New Yorker. Available at: (https://www.newyorker.com/business/currency/where-nokia-went-wrong) (22.02.2019).

Tauqeer, M. and Bang, K. (2018), "Servitization: A Model for the Transformation of Products into Services through a Utility-Driven Approach", Journal of Open Innovation: Technology, Market, and Complexity, Vol. 4 No. 4, p. 60. https://doi.org/10.3390/joitmc4040060

Van Halen, C., Vezzoli, C. and Wimmer, R. (2005), "Methodology for product service system innovation: how to develop clean, clever and competitive strategies in companies", Uitgeverij Van Gorcum.

Vargo, S.L. and Lusch, R.F. (2008), "Service-dominant logic: continuing the evolution", Journal of the Academy of marketing Science, Vol. 36 No. 1, pp. 1-10. https://doi.org/10.1007/s11747-007-0069-6 
Vasantha, G.V.A., Roy, R., Lelah, A. and Brissaud, D. (2012), “A review of product-service systems design methodologies”, Journal of Engineering Design, Vol. 23 No. 9, pp. 635-659. https://doi.org/10.1080/09544828.2011.639712

Visnjic, I., Wiengarten, F. and Neely, A. (2014), “Only the Brave: Product Innovation, Service Business Model Innovation, and Their Impact on Performance”, Journal of Product Innovation Management, Vol. 33 No. 1, pp. 36-52. https://doi.org/10.1111/jpim.1225 